\title{
WHAT DO WE LEARN FROM ALTERNATIVE EDUCATION INSTITUTIONS FOR LEARNING INNOVATIONS?
}

\author{
Lina Yordanova ${ }^{1}$, Gabriela Kiryakova ${ }^{2}$, Nadezhda Angelova ${ }^{2}$ \\ ${ }^{1}$ Department for Information and In-Service Teachers Training, \\ Trakia University of Stara Zagora, Bulgaria \\ Armeyska 9, 6000 Stara Zagora, Bulgaria \\ phone: +35942670240, e-mail: lina.yordanova@trakia-uni.bg \\ ${ }^{2}$ Faculty of Economics, Trakia University of Stara Zagora, Bulgaria \\ Studentski grad, 6000 Stara Zagora, Bulgaria, phone: +35942699440 \\ e-mail: gabriela.kiryakova@trakia-uni.bg,nadezhda.angelova@trakia-uni.bg
}

\begin{abstract}
The article presents the results from a survey on the innovative work models of the alternative educational organizations in Bulgaria. The analysis aims to answer to the question whether the institutions of interest could serve as a model or, at least, as a corrector of the education process organization held in our university. Many alternative training organizations were objects of the study in the frame of this project but here only two examples are given - SoftUni and Aula.bg. First one is representative of university type institution but second one works as a Center for online training. A group of students is included into the project team and to facilitate the survey a net of information nodes is defined to be followed and filled in during the evaluation of alternative organizations training methods. The concepts of innovation and disruptive innovation are discussed in their relation to education. A list of common characteristics of the training activities and methods of the observed institutions is offered and discussed. The main conclusion is that most of listed approaches and methods could be implemented in each state university with small exceptions. For example, the process of accepting new subject or study plan is very long and difficult following the state regulations for High education. The accreditation process of a new specialty takes years. The flexibility and actuality of the subjects seem to be unreachable for the state universities.
\end{abstract}

Keywords: innovative education models, education principles, education institutions.

\section{INTRODUCTION}

Last ten years there are a lot of private organizations in our country that have obtained the license to offer and organize some kinds of training for specific target group of people. Such approach could provide a big support of national education system in term of LLL (Life Long Learning) ideas. To this group of organizations are included non-government communities that develop, deliver or promote the results of Bulgarian or international projects devoted especially for the creation of training resources. All these alternative institutions are attractive and play a competition role of the universities from another side. Their work seems to be as an alternative of services offered by state universities. They become popular and famous for the society more and more and this provokes and motivates current study.

A survey on the innovative models for work of the alternative educational organizations in Bulgaria has been held in the frame of a project of Faculty of education, Trakia University. The goal is to answer to the question whether the observed institutions could serve as a model or, at least, as a corrector of the education process organized in our university.

IRTIIE Vol. 7, No. 1, 2019 ISSN 1314-8788 (print), ISSN 1314-8796 (online), doi: 10.15547/artte.2019.01.008 


\section{METHODS}

The following tasks was determined and completed during the presented here project:

- Analysis of the offered forms of education,

- Determining their advantages and disadvantages,

- Tracking their results,

- Comparison with classical forms of education.

In order to conduct the current study next main information nodes were defined and used.

\subsection{Objects of the study}

Alternative education institutions are all organizations that have deliver training but are not Higher Education Institutions. They offer their educational services primarily through the means and services of the Internet. They organize their activities either according to their own ideas or as a result of national or European projects

\subsection{Characteristics of the objects of interest}

Recognizing the institution as educational is done through the subject-matter of its activities, the licenses for its execution, the presentation of its mission, target group and the results of the training.

\subsection{Organization of training}

The way training is organized is a prerequisite for offering a quality service. We evaluate the organization of training as means of offering and promoting courses and modules; promoting this activity by the organization to reach the target group; learning objective and expected results; flexibility as forms of training and their timely organization; access to the courses paid, free of charge; forms of certification at the end of the training; trainers and venue; communication with learners before, during and after completion of the course.

\subsection{Training process}

Every successful and effective learning process is a subject to the main pedagogical principles. Their application enhances their qualitative characteristics and leads to the achievement of the training objectives. The focus of the study at this node is to evaluate whether the pedagogical principles of the learning process are applied by each discussed alternative educational institutions:

a) Principle of visibility - covering all perceptions by applying the different types of visuals (object-oriented, verbal, conditional, dynamic);

b) The principle of consciousness - Understanding the meaning of the knowledge, skills and habits by the learners, and a clear idea of the goals and importance of their own learning activity.

c) Principle of activity of the learner in the training - cognitive activity reflecting and showing the attitude of the trainee to the subject of training; emotional, intellectual, sensomotor, speech activity; motivation;

d) Accessibility Principle - Correspondence between the content and the training methods and the age specifics of learners; taking into account the level of training of the trainees and the extent of their cognitive development; Didactic accessibility rules - from easy to difficult, from familiar to unknown, from near to distant, from simple to complex;

IRTIIC Vol. 7, No. 1, 2019 ISSN 1314-8788 (print), ISSN 1314-8796 (online), doi: 10.15547/artte.2019.01.008 


\section{ARTTIE $Y$}

Ipplied Resseirlores in Technics, Technologies and Educration

Journal of the Faculty of Technics and Technologies, Trakia University https://sites.google.com/a/trakia-uni.bg/artte/

e) Principle of systemicity - knowledge, skills and habits are assimilated into a certain logical connection, in which the essential signs of the objects and phenomena and their totality constitute an integral entity or system. The application of logical operations such as classification and comparison are of great importance for the didactic system achievements. Existence of training plans, programs and modules for training.

f) Principle of durability of knowledge, skills and habits - to assimilate them with thoroughness and durability; reproduce and apply the essentials of the material studied in different situations.

g) The principle of individual approach - taking into account the individual characteristics of the learners in terms of learning; crucial to achieving a successful and effective learning process; requires observation, talks, polls, and more. Research methods for the preliminary determination of individual abilities/peculiarities of learners for perception, understanding and in general for mental work.

The authors of the survey think that it is not necessary to cite pedagogical researchers here as each university book on pedagogy or didactics deals, explains, illustrates or offers interpretations of these classical pedagogical principles. [3] In our days classical pedagogical principles are object of changing or complimenting via the new kinds of pedagogics established as a response of our new technological environment. Here a simple interpretation is offered do be appropriate for the students - participants in cited project.

\subsection{Learning outcomes}

Here it is necessary to pay attention to the statistics of the learning outcomes of the users of these educational services.

\section{EXPERIMENTAL}

The current article also illustrates some results of the experimental work in the frame of a project in Faculty of education that aims to direct a group of student on Pedagogic of education on Information technologies to the research work. The above mentioned set of information nodes supports the individual or group work of the project team students who have the task to explore separate alternative educational institutions and organizations. These can be considered as criteria for assessing whether the institutions surveyed offer training that could serve as a model or at least to make adjustments to the training organization that takes place at our university.

\subsection{Innovative methods and forms of teaching}

For the purposes of this study the term "Innovative methods and forms of teaching/training" need to be defined and specified. Generally, teaching methods based on Information and Communication Technologies (ICT) are accepted like innovative.

\subsubsection{Innovation}

"Innovation is the use of new ideas, processes, goods, services and practices in a more or less commercial way based on a new application of science and/or technology." [2]

In 2014 survey of literature on innovation found over 40 definitions of the term "innovation". [1] The main characteristic of an innovation is that it is resulting in a new product, service, process or form of organization. The last could have an important value in education and could lead to effectiveness into the process of learning and teaching.

IRTIIE Vol. 7, No. 1, 2019 ISSN 1314-8788 (print), ISSN 1314-8796 (online), doi: 10.15547/artte.2019.01.008 


\subsubsection{Disruptive innovation}

The term "disruptive innovation" is used in business and technology and describes innovations that change and refine products and services in an unexpected way. It means introducing new technologies, offering new products, or organizing new services to ensure change and growth. It is used in the sense of substitution, not as interruption and destruction. In business, disruptive innovations can be very risky because they cause drastic, radical changes in production development approaches and companies' presence on the market. But they create new opportunities where they did not exist. Cell phones, digital cameras, ebook readers, and more are examples of disruptive innovations that give us new opportunities and without which we can hardly fulfill our daily obligations. [4, 5]

On the other hand, disruptive innovation means offering an alternative to an existing product that is simpler, cheaper or more convenient. These last features are preferable in the area of education too.

\subsection{Students activities}

The students, member of the project team have to make the analysis of the offered forms of education, determination of the advantages and disadvantages of separate institutions and track the results comparing the classic forms of education.

In the initial review of the work of the alternative educational institutions, some of the information nodes from Section 2 were applied. It is about to summarize the results of the students obtained from the full application of the proposed research network. The resources, tools and methods available to organizations, the link between the knowledge and skills they offer are clear and recognized. A summary classification of alternative education institutions can be made as it is presented in next section.

\section{RESULTS}

\subsection{Common characteristics for the training activities of the observed institutions}

The main observations on the work of the alternative education organizations are as follows:

- These institutions teach people from all over the country by organizing training in two main forms - present and online (distance);

- They have their own Web sites that are their platforms for organizing courses, conducting the training and the exams, self-preparation and self-examination of the knowledge by students, providing information about the whole activity.

- The learning resources they provide are in a variety of electronic formats, mostly video materials and presentations in pdf format.

- The communication with learners is done through emails, social networks', and YouTube channels or one could say they use the so-called social informatics.

- The offered training is really on demand, as stated in the innovative educational model when recruiting a sufficient number of people willing to organize a new course.

- They organize events such as competitions, seminars, etc. with the participants in the courses.

- They show flexibility, dynamism, innovation in their work.

- Experienced specialists, albeit young, are used by lecturers. They do not matter university degrees, but experience and modern knowledge and skills.

- All the modules of the training courses are modern, contemporary and up-to-date and presented in the most practical way motivating for learning and learning at all.

- People who use their services are mostly motivated by the desire to work later on IRTIIE Vol. 7, No. 1, 2019 ISSN 1314-8788 (print), ISSN 1314-8796 (online), doi: 10.15547/artte.2019.01.008 


\section{ARITIE}

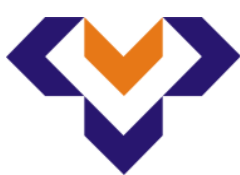

Ipplied Resseirlores in Technics, Technologies and Educration

Journal of the Faculty of Technics and Technologies, Trakia University https:///ites.google.com/a/trakia-uni.bg/artte/

something that is new and well paid. The best trainees are being offered real jobs.

- These organizations are either companies in the IT sector or they have closed links to business in this sector.

- Some of them have licenses for their work issued by the Ministry of Education and Science.

- They develop their services by offering free courses for certain target groups and formulating their curriculum for obtaining qualifications from a specific area. Any national comities do not prove the courses they provide.

- $\quad$ They use the Internet space not only for a direct learning process but also for promoting and advertising their activities.

\subsection{Examples}

\subsubsection{Software University (SoftUni)}

Some interesting observations are made about the work of Software University (SoftUni) the most active alternative educational institution in Bulgaria.

They work according the license given by Ministry of Education and Science and very well understand their mission "Change digital future of Bulgaria" (Figure 1).

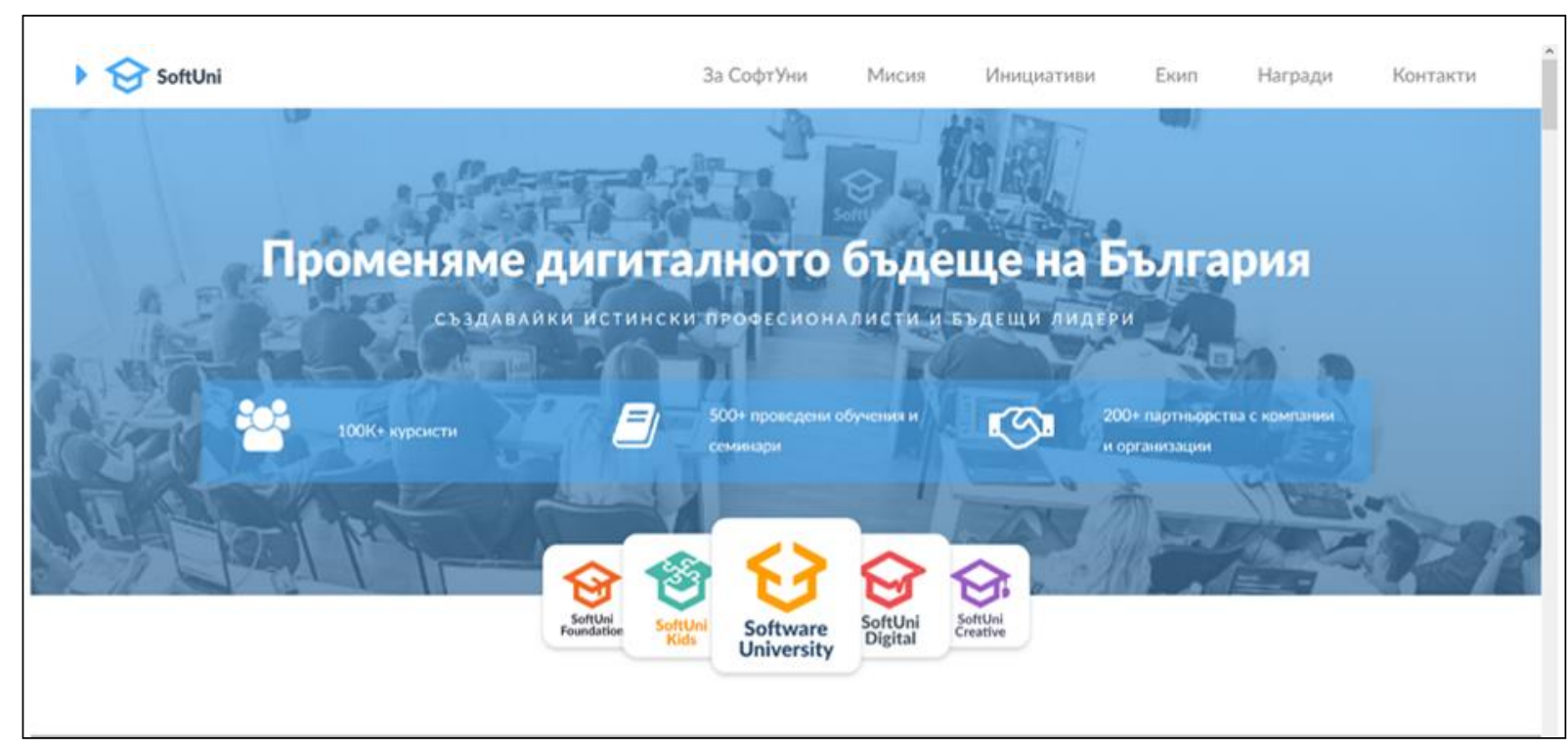

Figure 1. The main page of SoftUni site

SoftUni has an ambition mission "to provide high quality and accessed education in the field of IT and digital world, creating real professionals and future liders, contributing for realization of a dream, Bulgaria - Silicon Valley of Europe." This can be read on their site.

The site is simple and easy to navigate and in the same time very informative. The main page of their site gives the significant information about their activities and results. 100000 trainees, 500+ courses and 200+ partner companies and organizations in 2018. Five unites of SoftUni are shown symbolic way (Figure 1).

This institution offers two types or forms of education - attendance and distance training and require registration (Figure 2). One could note that the price of a course is comparable with half semester price in our university. The application form demands user registration and as a result regular emails inform about all new suggested courses in an attractive way.

IRTIII Vol. 7, No. 1, 2019 ISSN 1314-8788 (print), ISSN 1314-8796 (online), doi: 10.15547/artte.2019.01.008 


\section{ARTITE $Y$}

Ipplied Resseirlohes in Technics, Technologies and Eductition Journal of the Faculty of Technics and Technologies, Trakia University https://sites.google.com/a/trakia-uni.bg/artte/

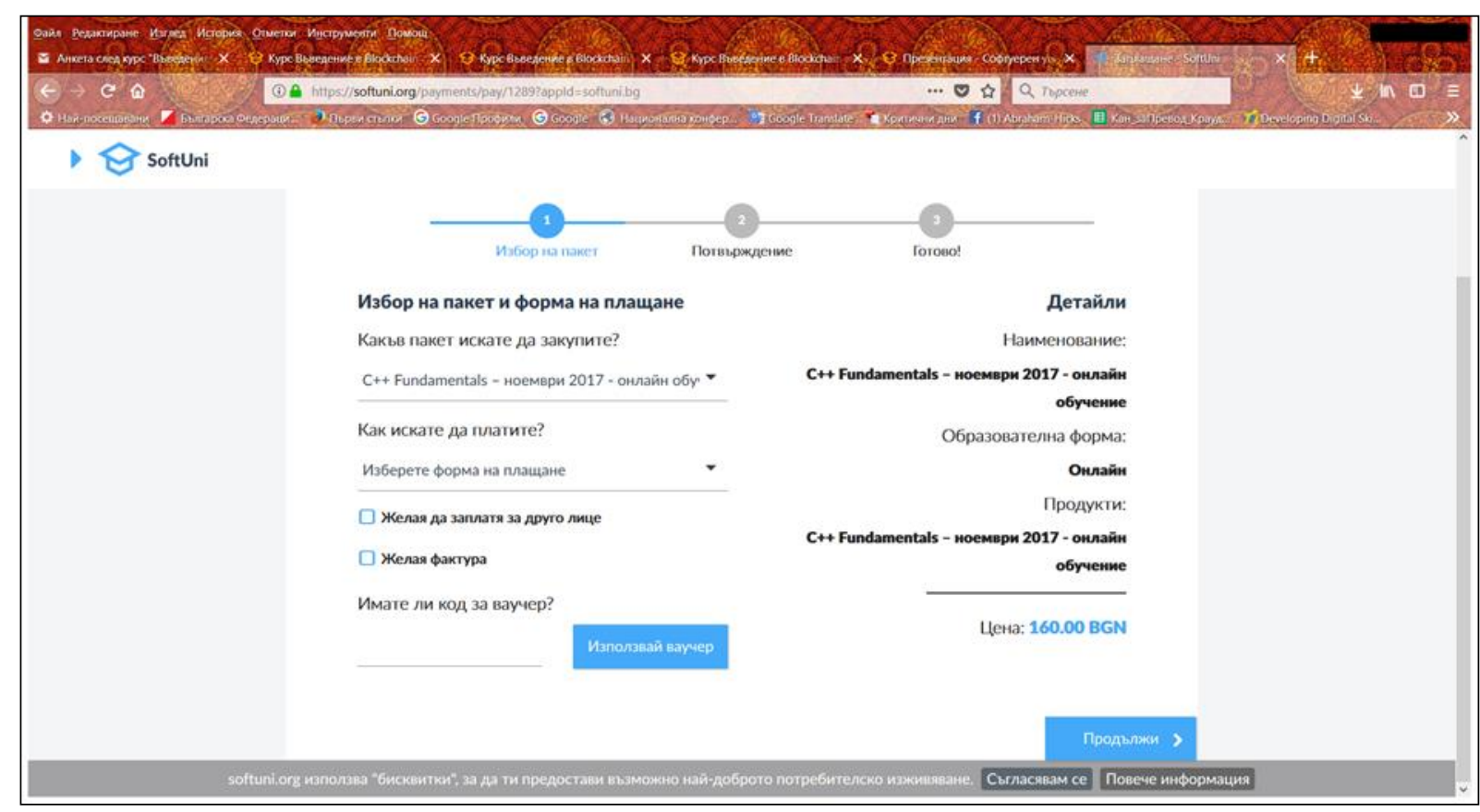

Figure 2. The registration form

To get a better idea of the education process some members of our project team participated in some courses of SoftUni. The courses duration is less 10 (8 often) weeks, lectures are once per week. The homework is a usual practice and the final test is paid additionally if a certificate is desired. Sometimes the lecturers are not professional educators and this a big disadvantage. As a rule this institution always employs experienced lecturers but not from the universities. A conclusion can be made that all contacts with universities are being avoided. Often organized courses are held in hotels' conference halls nevertheless local universities can provide good conditions. Although we all work in the interest of education and we want to improve its quality, the alternative educational organizations do not consider state universities as possible partners. SoftUni is not an exception.

Caring for trainees' career development is very attractive for people who take courses in SoftUni. Availability of Career Center works via partnerships with many business organizations.

One very important characteristics of SoftUni is permanent expansion of activity and looking for new perspectives. They work not only in the capital of the country, but some courses are offered for free in many cities in province. In such courses there is a decrease in quality and the use of trainees in previous courses as lecturers.

The good practice in SoftUni is introducing of new up to date topics in digital marketing, design, visualization, hardware technologies and robotics, artificial intellect and etc.

As it is shown in Figure 3 a very actual topics are offered always on time.

The pedagogical model implemented in SoftUni is "Learning by doing" as their focus is on acquiring practical skills. Theoretical knowledge are reduced as the purpose is to have short time education. The list of professionals educated in this institution is also not endless software engineer, digital marketing experts, system administrators, animators, $3 \mathrm{~d}$ visualizers but contemporary and modern.

A very useful idea to start courses for children on coding and robotics.

IRTIIE Vol. 7, No. 1, 2019 ISSN 1314-8788 (print), ISSN 1314-8796 (online), doi: 10.15547/artte.2019.01.008 


\section{ARTITE}

Ipplied Reseirl'ches in Technics, Technologies and Bduration Journal of the Faculty of Technics and Technologies, Trakia University https://sites.google.com/a/trakia-uni.bg/artte/

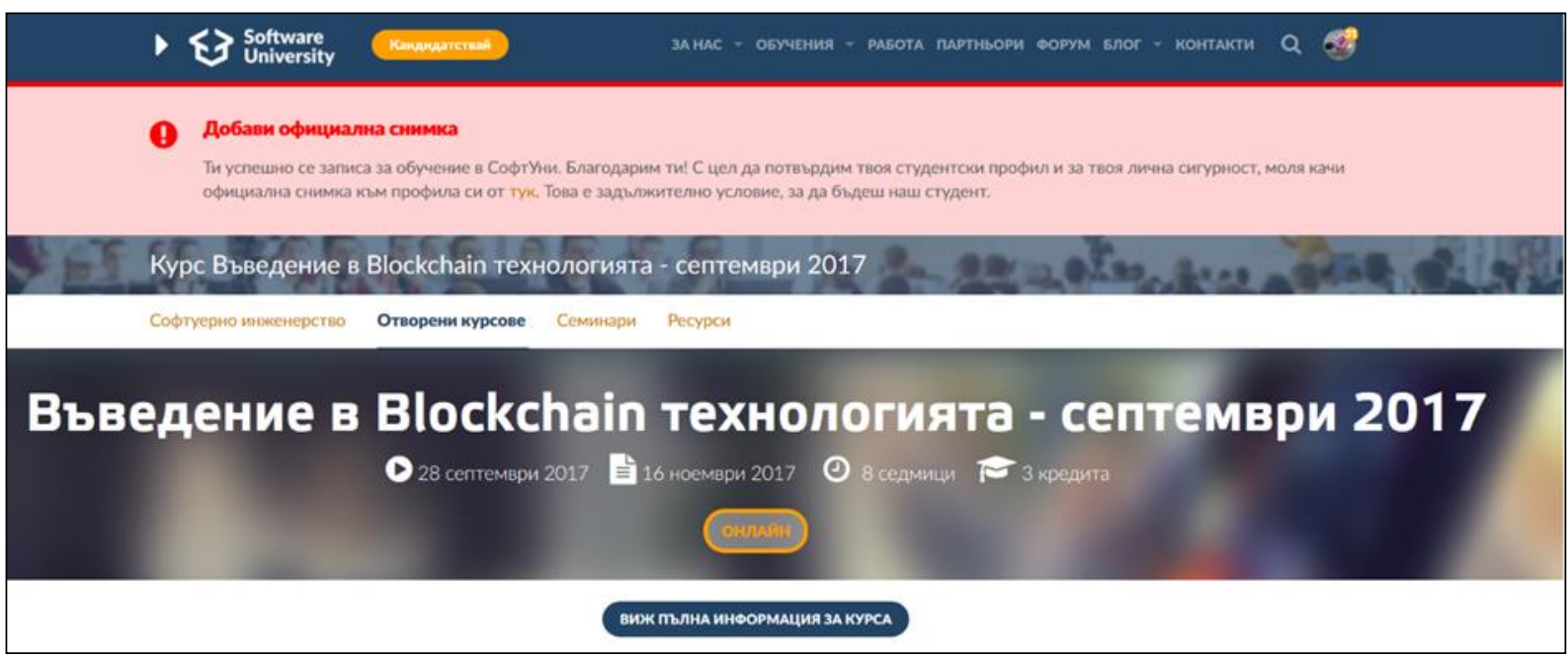

Figure 3. A course on Blockchain technology in 2017

The following items intend to direct the universities what could be learn from SoftUni:

- Actuality of the subject of the offered training - modern topics;

- Understanding educational goals - practical skills;

- Innovative Learning Model - Learning by doing;

- Easy and convenient site information - user friendly design;

- Motivation for teamwork - team task and social informatics in education;

- Teachers are good in their professional field, with much experience and desire to share knowledge - with some exceptions;

- Clarify the ultimate goal of learning and how you will achieve it - good for students to understand;

- Video for each of the courses - modern digital resources;

- Credit system used to motivate students;

- Practical communication skills - social media in education process;

- Requirements for the results before taking part into the next level course.

Most of above statement are achieved because people who participate in SoftUni courses are motivated in advance. Usually they have any previous education experience and they know what they want to learn. Diploma and certificate for an IT specialist is strongly desired for short time education.

\subsubsection{Aula.bg}

Aula.bg is a good example for advertising the education courses.

Aula.bg is a platform that offers courses on software topics for ICT users. It is presented as a Centre for online education as the goal is to teach people how to work with different kind of modern software products. In the end of 2018 almost 50 courses are offered. The online courses have very big advantage - one could study at the time that is convenient for him/her. Video lectures are reachable 24 hours per day. As a result 275426 Bulgarians have been participants in Aula.bg education.

What we can learn as university from Aula.bg? The answer is: how to advertise our work and results. Figure 4 represents the clear messages of Aala.bg in the ads included in Bulgarian news sites like news.bg and money.bg. The variety of images speaks a lot about the use of Internet advertising by this organization.

IRTIIE Vol. 7, No. 1, 2019 ISSN 1314-8788 (print), ISSN 1314-8796 (online), doi: 10.15547/artte.2019.01.008 


\section{IRTIIE}

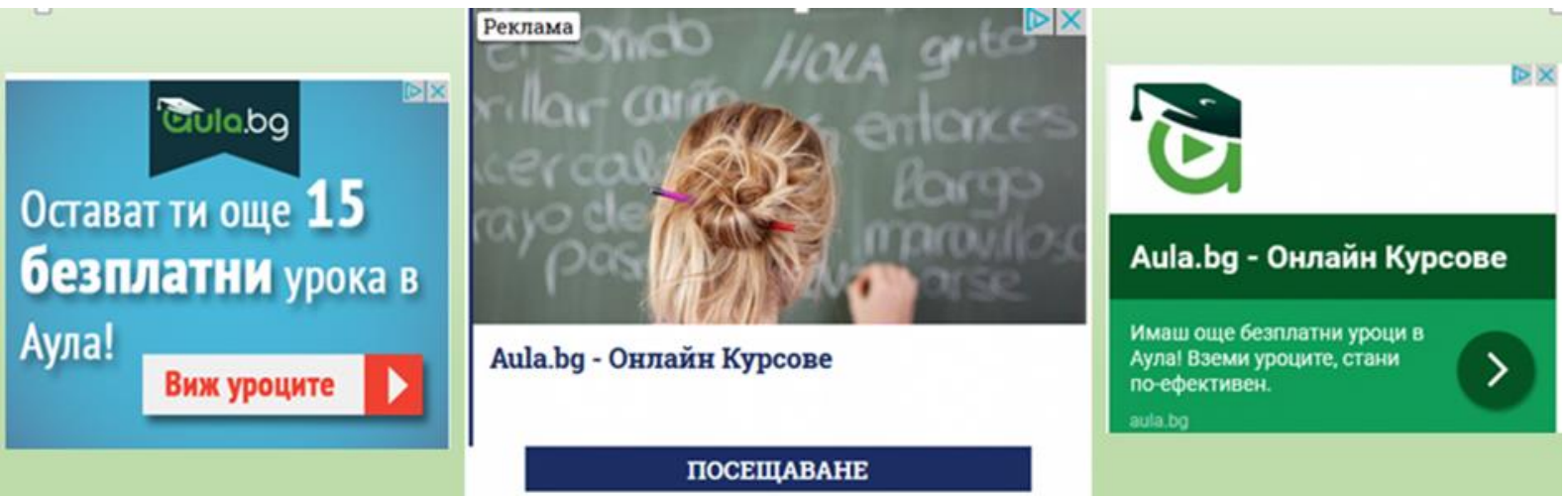

Figure 4. Ads of Aula.bg

Aula.bg uses advertising also in Facebook. Figure 5 is devoted on such sponsored event. The response of Facebook users is shown on the Figure 5 - for short time, less an hour 114 shares and 713 likes. Sponsored post in Facebook is like an investment that gives the result in increasing the visitors of the given organization site.

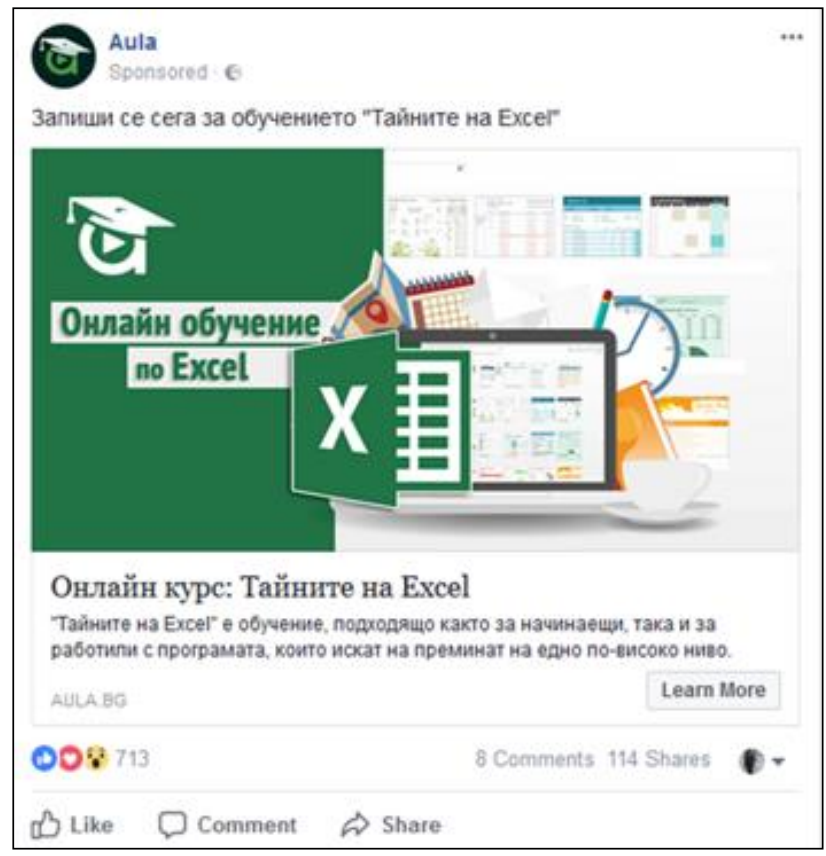

Figure 5. Sponsored post in Facebook of Aula.bg

\section{CONCLUSIONS}

The current study presented the base part of a project work devoted to a research on alternative educational organizations which are considered as concurrent of state universities with very successful performance and raised popularity. The goal is to determine their best sides and direct further organization of university educational process into the modern and liked way of training.

Two examples are taken here as representative of two groups of alternative educational organizations: first the university type group and second online training centers group.

IRTIIE Vol. 7, No. 1, 2019 ISSN 1314-8788 (print), ISSN 1314-8796 (online), doi: 10.15547/artte.2019.01.008 


\section{ART'TE

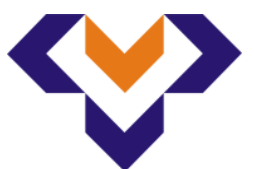 \\ Ipplied Resseirlores in Technics, Technologies and Educration \\ Journal of the Faculty of Technics and Technologies, Trakia University https://sites.google.com/a/trakia-uni.bg/artte/}

For the first group the next conclusions could be made:

- They apply innovative ways to motivate the learners.

- They use social informatics approaches.

- All communication channels are actively used by them.

- $\quad$ The method "learning by doing" is implemented in educational process.

- They provide realization to the best students, motivate them to become best to help them find a better job.

- $\quad$ They constantly expand their activities.

- The topics are not restricted to IT fields. Varity of workshops and courses related to personality development, teamwork, communication are suggested also.

- They have strong relationships with the business.

For the second group of alternative educational institutions video learning materials, accessible 24 hours per day, 7 days per week have crucial role. The university teachers could create well learning video after correspond training. Aula.bg business model is also applicable of a given university for advertising the education.

Most above mentioned approaches here could be implement in each state university with small exceptions. For example, the process of accepting new subject or study plan is very long and difficult following the state rules for High education. The accreditation process of a new specialty takes years. The flexibility and actuality seem to be unreachable.

Each educational institution can implement the innovative educational model by relying on selected and appropriate IT tools.

The wide variety of ICT tools for choice, freely available or shared resources creates an invaluable opportunity for an educational institution to move on to a higher level of work and to offer an innovative educational service.

Technologies are becoming more and more innovative, but whether the institution itself is ready to integrate them successfully and effectively into the learning process.

Obviously, we need such an organization of the learning process that best coincides with the idea of activity, commitment and creativity. On both sides - the trainers and the trainees.

\section{REFERENCES}

[1] Anderson N., Potočnik K., Zhou J. (2014). Innovation and Creativity in Organizations: A State-of-the-Science Review, Prospective Commentary, and Guiding Framework. Journal of management. Vol. 40. Issue 5, pp. 1297-1333. https://doi.org/10.1177/0149206314527128.

[2] Kanter R. M. (1989). When the Giants Learn to Dance, London.

[3] Radev PI. (2003). Pedagogics. Plovdiv, Hermes, 2003.

[4] Yordanova L. (2014). Disruptive innovation model in education. Proceedings of international conference "Education policies in $21^{\text {st }}$ century“, (2014), ISBN 978-61990168-3, pp 71-75.

[5] Massa L. \& Tucci C. L. (2014). Business Model Innovation. In M. Dodgson, D. M. Gann, \& N. Phillips (Eds.). The Oxford Handbook of Innovation Management, pp. 420-441, Oxford, UK, Oxford University Press. 